BMC

Developmental Biology

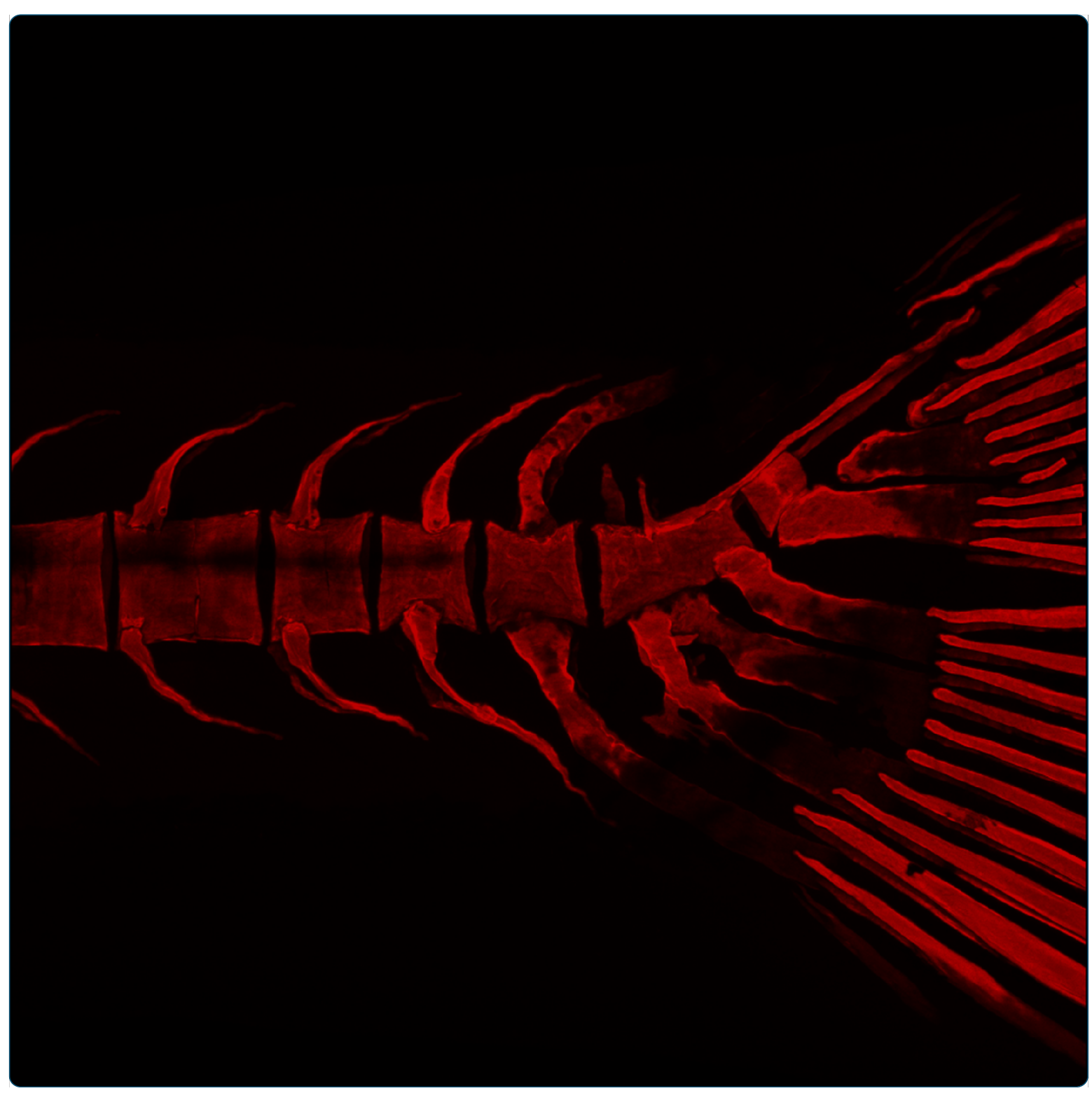

Distinct patterns of notochord mineralization in zebrafish coincide with the localization of Osteocalcin isoform 1 during early vertebral centra formation

Bensimon-Brito et al. 


\title{
Distinct patterns of notochord mineralization in zebrafish coincide with the localization of Osteocalcin isoform 1 during early vertebral centra formation
}

Anabela Bensimon-Brito 1,2,3,5, João Cardeira², Maria Leonor Cancela ${ }^{2,4^{*}}$, Ann Huysseune ${ }^{3}$ and Paul Eckhard Witten ${ }^{3^{*}}$

\begin{abstract}
Background: In chondrichthyans, basal osteichthyans and tetrapods, vertebral bodies have cartilaginous anlagen that subsequently mineralize (chondrichthyans) or ossify (osteichthyans). Chondrocytes that form the vertebral centra derive from somites. In teleost fish, vertebral centrum formation starts in the absence of cartilage, through direct mineralization of the notochord sheath. In a second step, the notochord is surrounded by somite-derived intramembranous bone. In several small teleost species, including zebrafish (Danio rerio), even haemal and neural arches form directly as intramembranous bone and only modified caudalmost arches remain cartilaginous. This study compares initial patterns of mineralization in different regions of the vertebral column in zebrafish. We ask if the absence or presence of cartilaginous arches influences the pattern of notochord sheath mineralization.
\end{abstract}

Results: To reveal which cells are involved in mineralization of the notochord sheath we identify proliferating cells, we trace mineralization on the histological level and we analyze cell ultrastructure by TEM. Moreover, we localize proteins and genes that are typically expressed by skeletogenic cells such as Collagen type II, Alkaline phosphatase (ALP) and Osteocalcin (Oc). Mineralization of abdominal and caudal vertebrae starts with a complete ring within the notochord sheath and prior to the formation of the bony arches. In contrast, notochord mineralization of caudal fin centra starts with a broad ventral mineral deposition, associated with the bases of the modified cartilaginous arches. Similar, arch-related, patterns of mineralization occur in teleosts that maintain cartilaginous arches throughout the spine.

Throughout the entire vertebral column, we were able to co-localize ALP-positive signal with chordacentrum mineralization sites, as well as Collagen II and Oc protein accumulation in the mineralizing notochord sheath. In the caudal fin region, ALP and Oc signals were clearly produced both by the notochord epithelium and cells outside the notochord, the cartilaginous arches. Based on immunostaining, real time PCR and oc2:gfp transgenic fish, we identify Oc in the mineralizing notochord sheath as osteocalcin isoform 1 (Oc1).

(Continued on next page)

\footnotetext{
*Correspondence: Icancela@ualg.pt; PEckhardWitten@aol.com

${ }^{2}$ Center of Marine Sciences - CCMar, University of Algarve, Faro, Portugal

${ }^{3}$ Evolutionary Developmental Biology, Biology Department, Ghent University,

Ghent, Belgium

Full list of author information is available at the end of the article
} 


\begin{abstract}
(Continued from previous page)
Conclusions: If notochord mineralization occurs prior to arch formation, mineralization of the notochord sheath is ring-shaped. If notochord mineralization occurs after cartilaginous arch formation, mineralization of the notochord sheath starts at the insertion point of the arches, with a basiventral origin. The presence of ALP and Oc1, not only in cells outside the notochord, but also in the notochord epithelium, suggests an active role of the notochord in the mineralization process. The same may apply to Col Il-positive chondrocytes of the caudalmost haemal arches that show ALP activity and Oc1 accumulation, since these chondrocytes do not mineralize their own cartilage matrix. Even without cartilaginous preformed vertebral centra, the cartilaginous arches may have an inductive role in vertebral centrum formation, possibly contributing to the distinct mineralization patterns of zebrafish vertebral column and caudal fin vertebral fusion.
\end{abstract}

Keywords: Vertebral column, Vertebral fusion, Notochord, Osteocalcin

\section{Background}

The structural units of the vertebral column are the vertebrae, composed of neural and haemal arches and the vertebral body itself, the centrum. Vertebral bodies are joined by intervertebral tissue primarily derived from the notochord [1-3].

The vertebral column results from a strictly controlled segmentation process that occurs in all vertebrate species and is associated to two main structures, the notochord and the somites $[4,5]$. The somites are epithelialized spheres of mesoderm that develop on either side of the neural tube, give rise to dermis, skeletal musculature (dermomyotome) and vertebrae (sclerotome) [6,7]. While the somite contribution to vertebra formation has been extensively studied, particularly in birds $[6,8]$, the role of the notochord has received less attention. In teleosts, the majority of extant vertebrates, the notochord is composed of a core of large, vacuolated chordocytes, and an epithelial layer of chordoblasts that secrete the notochord sheath [9]. The notochord sheath is a stratified structure, composed of a thin external membrane, with high elastin content, covering a thicker collagenous layer $[10,11]$.

In chondrichthyans and most osteichthyans, including tetrapods, but not in teleosts, vertebral bodies have a cartilaginous anlage that subsequently either mineralizes or is replaced by bone. In teleosts such as zebrafish, vertebral centra are formed in the absence of cartilage $[12,13]$. Indeed, teleost vertebral centra form through the mineralization of the notochord sheath (chordacentrum), which is then surrounded by somite-derived intramembranous bone (autocentrum) [2,12,14-16].

In teleosts, such as Atlantic salmon (Salmo salar) or zebrafish (Danio rerio), the notochord plays an important role in early life stages, as its mechanical function is only replaced by the vertebral column in the postembryonic life $[2,17,18]$. In Atlantic salmon, the initial mineralization of the chordacentrum has been described to be associated with cells of the notochord epithelium (chordoblasts), while bone formation, by sclerotome- derived cells (autocentrum), is a second step [2]. In contrast, Inohaya and co-workers suggest that in medaka (Oryzias latipes), only sclerotome-derived cells are involved in chordacentrum and autocentrum mineralization, with no role of chordoblasts [19]. Yet, a recent study [20] shows that, also in medaka, with conditional ablation of osterix-positive osteoblasts, notochord sheath mineralization is maintained. Therefore, the main cellular and molecular determinants involved in early notochord mineralization are still under debate. Furthermore, the role of extracellular matrix proteins such as osteocalcin, generally expressed by mature and resting osteoblasts [21] and by hypertrophic chondrocytes [17,22-24], in that process, remains unclear. In several teleosts, including zebrafish, two Osteocalcin genes (Oc1 and Oc2) have been identified [25].

In amniotes the vertebral column is divided into five main regions whereas the vertebral column of teleosts is often only subdivided into two main regions, abdominal and caudal (e.g., [26-28]). However, also in zebrafish, several regions can be recognized within the vertebral column. In particular, regions that contain the most anterior and the most posterior vertebrae are highly specialized [15,29]. Regional differences are not only apparent at the morphological level but also regarding the tendency of vertebrae to fuse. While zebrafish vertebral bodies usually display no pathological fusion [30], caudal fin vertebrae undergo several fusions as part of regular development [15,30-32]. Yet, other teleosts, such as Atlantic salmon and other farmed species, are known to suffer frequent pathological vertebral fusions [33,34]. Whether regional differences in vertebrae morphology and mineralization relate to the susceptibility to fuse remains an open question.

This study aims to characterize mineralization patterns in different regions of the vertebral column (abdominal, caudal, caudal fin region) using various methods to reveal mineral deposition. Subsequently, these patterns are compared with the histogenesis of the arches, revealed through Collagen type II immunostaining, and to the 
timing of centrum formation. We characterize the proliferation of notochord cells and we also localize proteins related to mineralization, such as Alkaline phosphatase and Osteocalcin. We here provide the first evidence for the early presence of Osteocalcin 1 in mineralizing chordacentra. Finally, we discuss a possible association between timing of centra formation, the mineralization pattern and occurrence of vertebral fusion.

\section{Results}

\section{Centrum mineralization follows arch formation in the} caudal fin region

The fully developed zebrafish vertebral column displays a mode of 33 vertebral bodies (Figure 1 ) including 4 centra in the Weberian apparatus, 10 abdominal vertebrae, 15 caudal vertebrae, and 3 to 4 caudal fin vertebrae (depending on the presence of a fourth preural) [15].

The first centra to mineralize (Figure 2a) are 3 and 4 (4.0 $\mathrm{mm} \mathrm{TL})$ in an anterior-to-posterior direction, followed by the mineralization of centrum 5 , and later centra 1 and 2 , in specimens of $4.4 \mathrm{~mm} \mathrm{TL}$. The mineralization of the remaining abdominal and caudal centra follows an anterior-to-posterior direction (Figure 2b). The mineralization of the caudal fin centra starts with the $\mathrm{U} 1$ from the compound centrum $\left[\mathrm{PU} 1^{+}+\mathrm{U} 1\right]$, in specimens of $5.5 \mathrm{~mm}$ TL (Figure 2b). PU2 is the last centrum to be formed, in specimens of $6.7 \mathrm{~mm} \mathrm{TL}$, preceded by PU3 formation (Figure 2c). By then, the complex cartilaginous structure that forms the Weberian apparatus is already present in the anterior part of the vertebral column.

All Weberian, abdominal and caudal centra mineralize before development of the arches (Figure 3a). In the Weberian region, the haemal and neural arches develop as cartilaginous anlagen. These are Collagen type II positive, except for the associated spines that have no cartilaginous precursor. In the abdominal and caudal regions, the arches develop as intramembranous bones, with no cartilaginous anlage.

In contrast, in the modified caudal fin vertebrae, centrum mineralization occurs after arch formation. The (modified) arches associated to these centra have a cartilaginous anlage, also positive for Collagen type II. Staining of these arches was particularly strong at the bases (attachment areas to the notochord sheath) and distal parts, where no perichondral mineralization is present throughout the individual's life span. Collagen type II immunostaining also showed protein accumulation in the notochord sheath, although less evident than in the cartilage (Figure 3a').

In addition to the different timing of centrum mineralization versus arch formation, the present results also show a clear pattern concerning mineral expansion within the centra (Figure 3b, b', c, c').

With the exception of $\mathrm{C} 1$ and $\mathrm{C} 2$, vertebral bodies in the Weberian, abdominal and caudal regions start to mineralize in the form of a ring-shaped mineralized structure that expands in both anterior and posterior directions (Figure $3 b$ and b'). These centra will be referred to as "ring centra". In none of these vertebral bodies, have arches ever been observed prior to centrum mineralization. Nevertheless, the origin of mineralization matches the position of the myosepta, i.e. the site where neural and haemal arches will develop at a later stage. From this point, centrum mineralization expands one quarter anteriorly and three quarters posteriorly, showing clear incremental mineralization fronts (Figure $3 b^{\prime}$ ).

Different from this pattern, in the caudal fin (PU4/3 to $\mathrm{U} 2$ ) region, mineralization starts as a broad ventral mineral deposition (basiventral origin) (Figure 3c and $c^{\prime}$ ), which expands dorsally. Here, mineralization starts and expands from the attachment sites of the already developed modified cartilaginous haemal arches to the notochord. The developing centra show no apparent growth fronts as seen in the "ring centra" (Figure 3c').

\section{Inner and outer cell distribution during chorda- and autocentrum formation}

Irrespective of the shape of the mineralized centrum, ("ring" and caudal fin centra) (Figure 4a, b), the origin of mineralization was shown both with von Kossa staining (Figure 4c, c', d, d') and TEM (Figure 4e-f), to occur always

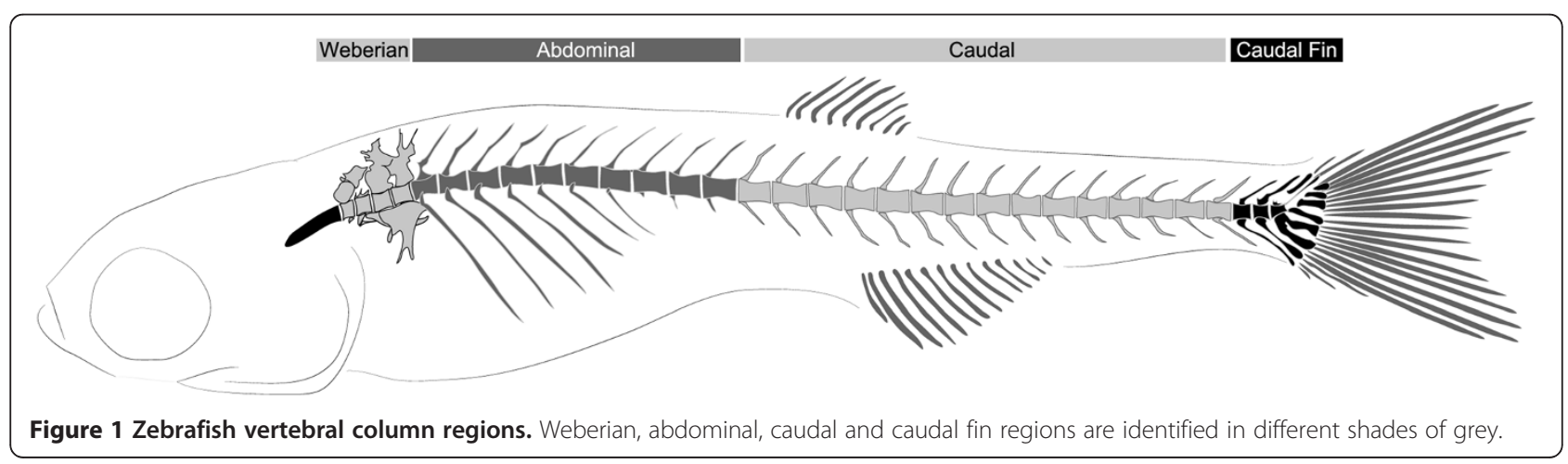




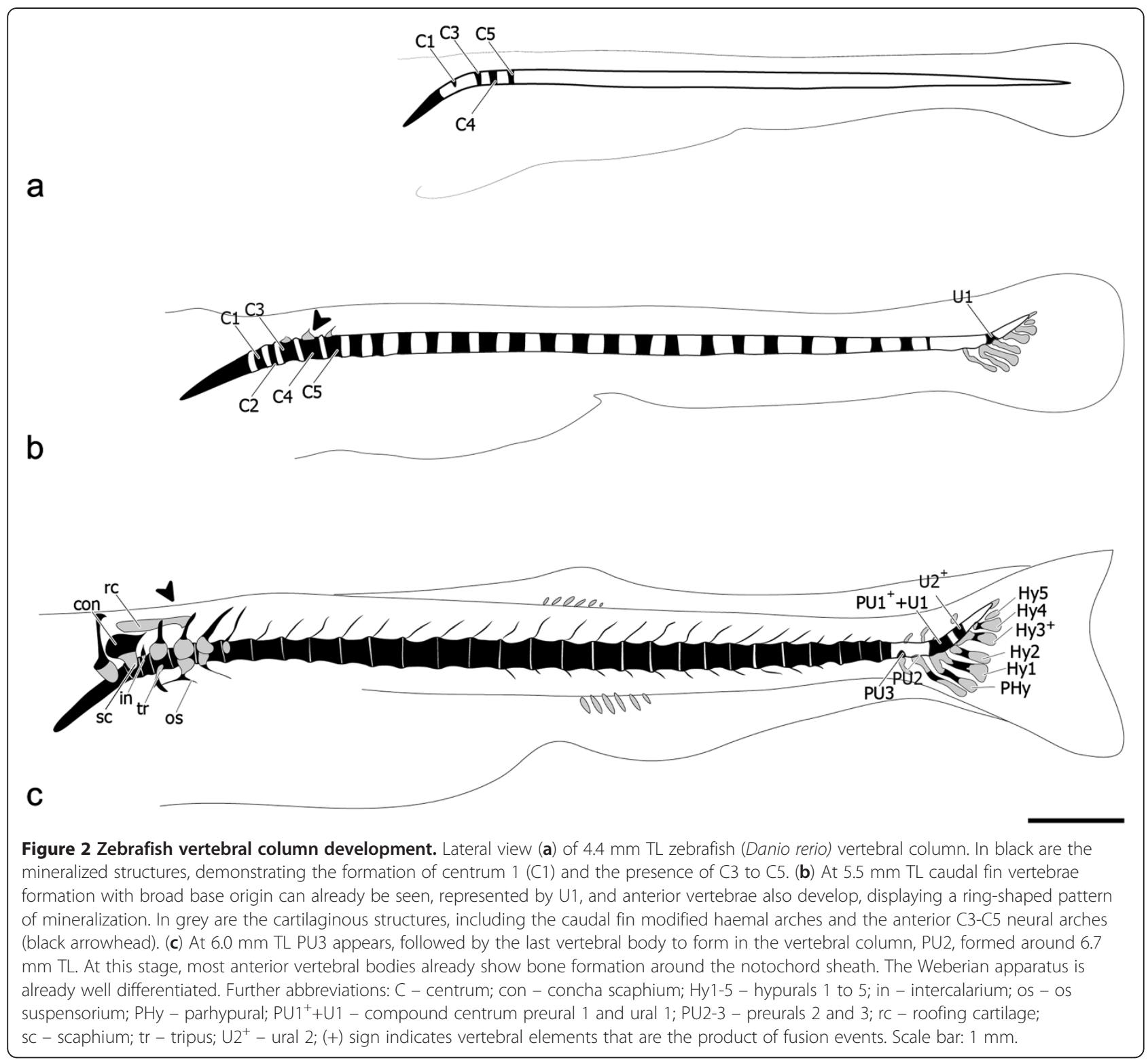

within the notochord sheath, thus establishing the chordacentrum. Once the chordacentrum is fully formed, perichordal bone is deposited mostly at the anterior and posterior edges, in this way establishing the vertebral endplates of the centra, thus forming the autocentrum (Figure 5a-d). Autocentrum formation occurs irrespective of the initial mineralization pattern within the notochord sheath ("ring" vs. basiventral origin). Yet, in the caudal fin centra, decreased bone formation is observed in the areas where cartilaginous arches attach to the notochord (Figure 5c-d).

During chordacentrum formation, notochord inner cells or chordoblasts do not accumulate in the prospective intervertebral space (Figure 4a, b), unlike what has been observed in other teleost species. However, once the centrum is mineralized, a higher number of chordoblasts can be seen in the non-mineralized intervertebral space (Figure 5a, c, e). By then, the chordoblasts are oblong, larger in size and are oriented in a dorsal-ventral direction (Figure 5e), as opposed to the squamous morphology displayed prior to and during chordacentrum development. In addition, chordoblasts proliferate in the intervertebral space, as shown by PCNA staining. Here, notochord sheath thickening occurs (Figure 5f). This pattern of chordoblast distribution is observed throughout the notochord, regardless of the type of centrum and its mineralization pattern (Figure 5a-d).

During chordacentrum formation, contrary to the inner notochord cells, the assumed sclerotome-derived notochord outer cells [35] in the "ring" vertebrae are 


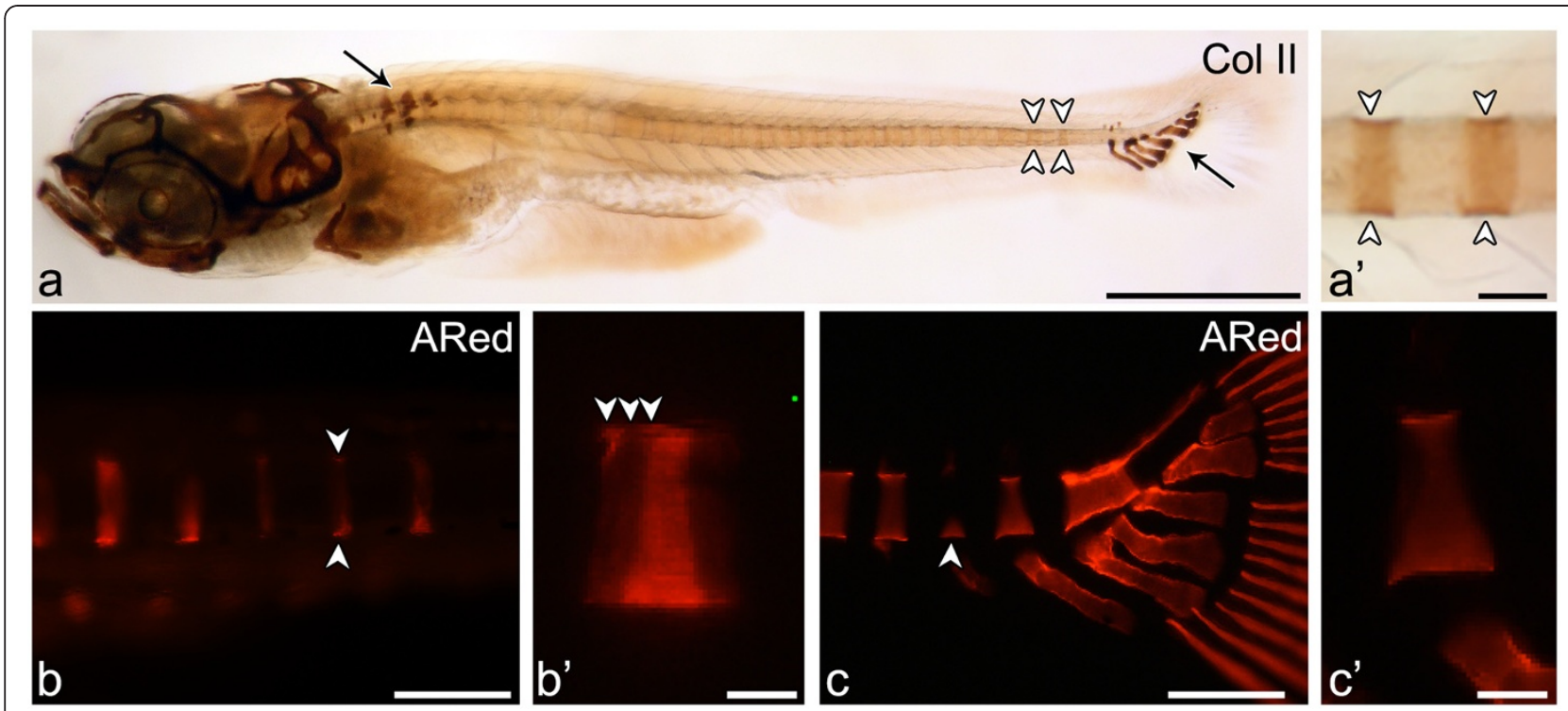

Figure 3 Early mineralization stages of vertebral centra and association with cartilaginous arches. Lateral view of (a, a') Collagen type II immunostaining in the vertebral column of a $5.9 \mathrm{~mm}$ TL zebrafish shows (a) protein accumulation mostly in the cartilaginous structures of the Weberian apparatus and of the caudal fin skeleton (arrows) but also in the notochord sheath (white arrowheads). (a') Although less evident than in cartilage, the staining can be clearly identified in the notochord matrix in a segmented manner (white arrowheads). (b-c) Early mineralization can be detected through alizarin red S (ARed) staining viewed under fluorescent light. (b) Early stage "ring" centrum (arrowheads) and (b') close up showing the mineralization fronts (white arrowheads) in $5.0 \mathrm{~mm}$ TL fish. (c) Caudal fin centrum mineralization with a basiventral origin (arrowhead) and $\left(\mathbf{c}^{\prime}\right)$ close up presenting a uniform mineralization surface with no distinct mineralization fronts, here represented by a $6.5 \mathrm{~mm} T \mathrm{TL}$ fish. Scale bars (a): $1 \mathrm{~mm} ;\left(\mathbf{a}^{\prime}\right) 0.1 \mathrm{~mm} ;(\mathbf{b}, \mathbf{c}): 0.15 \mathrm{~mm} ;\left(\mathbf{b}^{\prime}, \mathbf{c}^{\prime}\right) 30 \mu \mathrm{m}$.

visible as few scattered nuclei located around the notochord (Figure 4e). These cells are squamous and without apparent morphological features of active osteoblasts. In the caudal fin region, the cartilaginous haemal arches of the PUs (parhypural and hypurals 1, 2 and 4) directly attach to the notochord sheath with no space for other cells in-between the notochord sheath and the chondrocytes of the arches (Figure 4f).

During autocentrum formation, osteoblasts can be clearly identified in association with bone deposited around the "ring" chordacentra (Figure 5a). Major areas of the caudal fin chordacentra are covered by the cartilaginous arches attached to the notochord sheath surface (Figure 5c). Yet some osteoblasts can be identified wherever the arches are absent, lining the edges of the prospective vertebral endplates.

\section{Osteocalcin in chordacentrum formation}

In order to clarify possible factors in chordacentrum mineralization, both in "ring" and caudal fin centrum, we have localized Alkaline phosphatase (ALP) and Osteocalcin (Figure 6).

In "ring" centra, ALP-positive signal is co-localized with the site of chordacentrum mineralization prior to any bone deposition outside the notochord sheath. The flattened shape of both outer and inner notochord cells makes it difficult to clearly distinguish the origin of the
ALP signal, due to its membrane-bound characteristic (Figure 6a). In caudal fin centra, the arch chondrocytes, particularly those adjacent to the mineralizing notochord sheath, co-localize with a strong ALP signal (Figure 6b).

For Osteocalcin immunostaining, we used an antibody raised against Argyrosomus regius Oc1, which was previously validated [36]. It was considered to detect a single protein in zebrafish, since a western blot analysis gave a single band of approximately $5 \mathrm{kDa}$. Nevertheless we cannot guarantee that it distinguishes zebrafish Oc1 from Oc2. However, since Oc2 appears only after day 7 post-fertilization in zebrafish as shown by qPCR analysis (Figure 6l, m), immunostaining in younger fish, such as during formation of chordacentra $\mathrm{C} 1$ to $\mathrm{C} 5$ (Figure 2a) could only represent sites of Oc1 protein accumulation.

In "ring" (Figure 6c) and caudal fin centra (Figure 6d), Oc1 protein accumulation is observed in the mineralizing matrix of the notochord sheath, even at very early stages of chordacentrum formation. Oc1 accumulation co-localizes with chordacentrum mineralization, reflecting the exact same pattern as observed with alizarin red staining (Figure 3b, b', c, c'). Moreover, in later stages of centrum formation, we can detect progression fronts in "ring" centra (Figure 6e) while in caudal fin centra we observe homogenous protein accumulation (Figure 6f). In the caudal fin region, Oc1 is also detected in the 


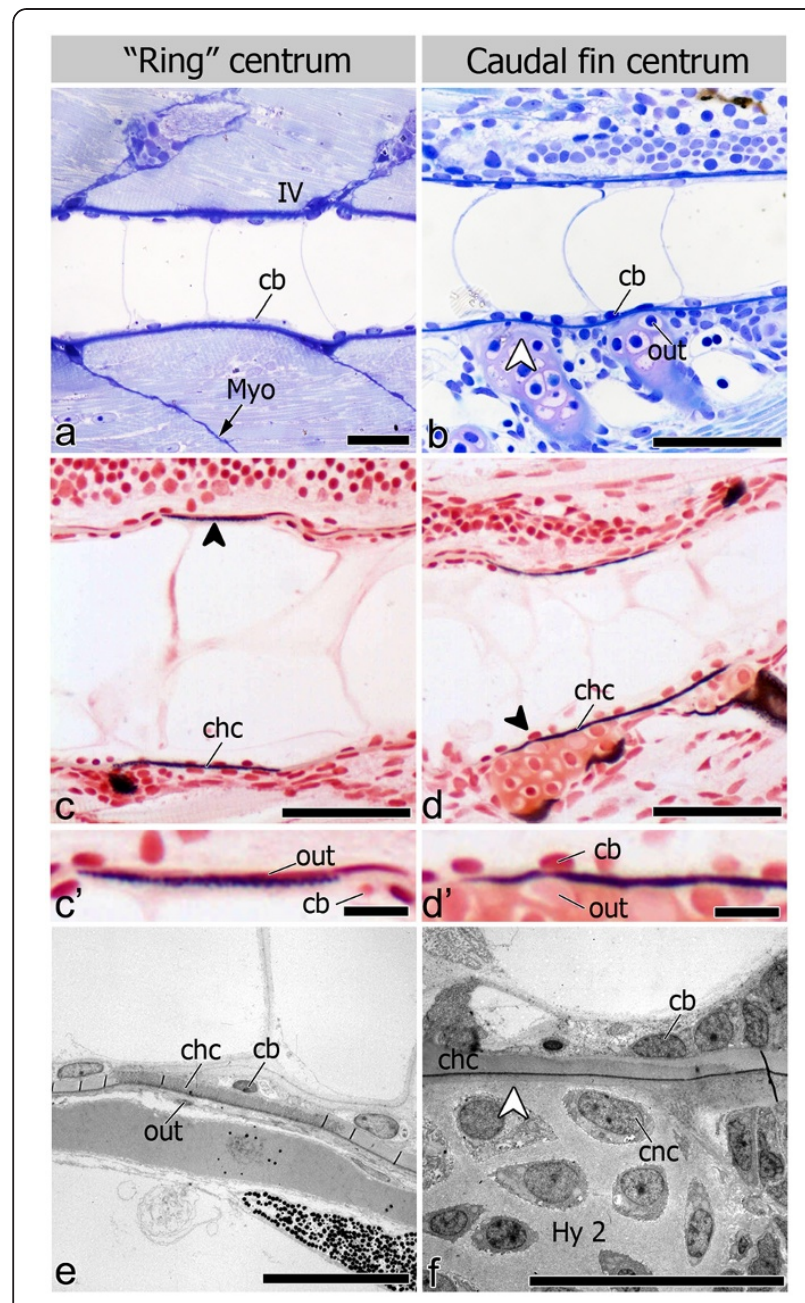

Figure $\mathbf{4}$ Chordacentrum formation and cell distribution inside and outside the notochord. Lateral view of $6.0 \mathrm{~mm}$ TL fish (a-d'). (a, b) Toluidine blue stained sections show the distinct morphologies of (a) "ring" and (b) caudal fin chordacentrum but homogenous chordoblast (cb) distribution during chordacentrum mineralization. In caudal fin vertebrae, outer (out) cells associated with the centra are chondrocytes from the cartilaginous arches (white arrowhead); (c and d) von Kossa staining highlighting that early (c) "ring" and (d) caudal fin centrum mineralization occurs within the notochord sheath, thus forming the chordacentrum (chc; black arrowheads); ( $\mathbf{c}^{\prime}$ and $\mathbf{d}^{\prime}$ ) details showing outer and inner cells

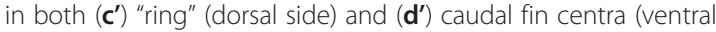
side). Lateral view of (e) $5 \mathrm{~mm}$ TL fish in TEM micrograph showing that both chordoblasts and outer cells (out) display a squamous morphology, associated with sites of "ring" chordacentrum mineralization, while in caudal fin centra ( $\mathbf{f}$ ) the cartilaginous matrix of the arches is directly attached to the notochord sheath (white arrowhead), leaving no space for cells other than chondrocytes (cnc) to interact with the chordacentrum outside the notochord (11 mm TL fish). Further abbreviation: Hy2 - Hypural 2; IV intervertebral space; Myo - myoseptum. Scale bars (a-d): $50 \mu \mathrm{m}$; $\left(\mathbf{c}^{\prime}, \mathbf{d}^{\prime}\right): 10 \mu \mathrm{m} ;(\mathbf{e}, \mathbf{f}): 20 \mu \mathrm{m}$.

vertebral arches and caudal fin rays (Figure 6d, f), which are examples of perichondral and intramembranous mineralization, respectively.
Analysis of semi-thin sections of the immunostained samples confirms accumulation of Osteocalcin in the notochord sheath and not around the notochord, during early (Figure 6g, g', h, h') and late (Figure 6i, j) stages of chordacentrum formation. In caudal fin centra (Figure $6 \mathrm{~h}, \mathrm{j}$ ), the arch chondrocytes adjacent to the mineralizing notochord sheath also co-localize with Oc1 protein (Figure 6h'), as observed for ALP. No perichondral ossification occurred in the arch at sites positive for ALP and Oc1, suggesting that these signals are not associated to arch ossification.

Observation of the transgenic fish $\operatorname{Tg}$ (oc2:gfp; osx: mcherry) showed that no oc2 expression is present during early stages of centrum formation. In fact, oc2 is completely absent during chordacentrum formation, appearing first in intramembranous formation of abdominal and caudal arches, a process previously described as mediated by mature osteoblasts (Figure 6k, k', k"). Analysis of relative $o c 1$ and $o c 2$ expression levels during zebrafish development shows that, while oc1 maternal transcripts are detected in early developmental stages, when no mature osteoblasts can yet be detected (Figure 6l), oc2 is only expressed after $7 \mathrm{dpf}$ (Figure 6m). Chordacentrum formation of the first vertebrae starts at $4.0 \mathrm{~mm} \mathrm{TL}$, as previously indicated, which, despite the natural variation in growth, corresponds to fish younger than 7 days.

\section{Discussion}

Zebrafish and medaka vertebral column development and morphology have been extensively described (e.g. $[1,12,19,29,31,37])$. Nevertheless, many questions remain unanswered. In particular, how do distinct mineralization patterns relate to regional differences in arch histogenesis and to susceptibility for vertebral fusion? Why do vertebrae in the caudal fin region fuse as part of the developmental process, in contrast to anterior regions where vertebrae remain individualized [15,30]?

Here, we describe two distinct mineralization patterns of vertebral centra associated with specific vertebral regions. We characterize these patterns based on (1) how mineral is being deposited throughout the centrum, (2) timing of development (prior to or after arch formation) and (3) arch histogenesis (intramembranous or cartilaginous origin). While describing this process we localized accumulation of $o c 1$ protein in mineralizing notochord sheath, suggesting it could play a function in early mineralization events during chordacentrum formation.

\section{Notochord segmentation, arch contribution to centra and association with fusion}

The first mineralization of the vertebral bodies, independent of the vertebral type (Weberian, abdominal, caudal 


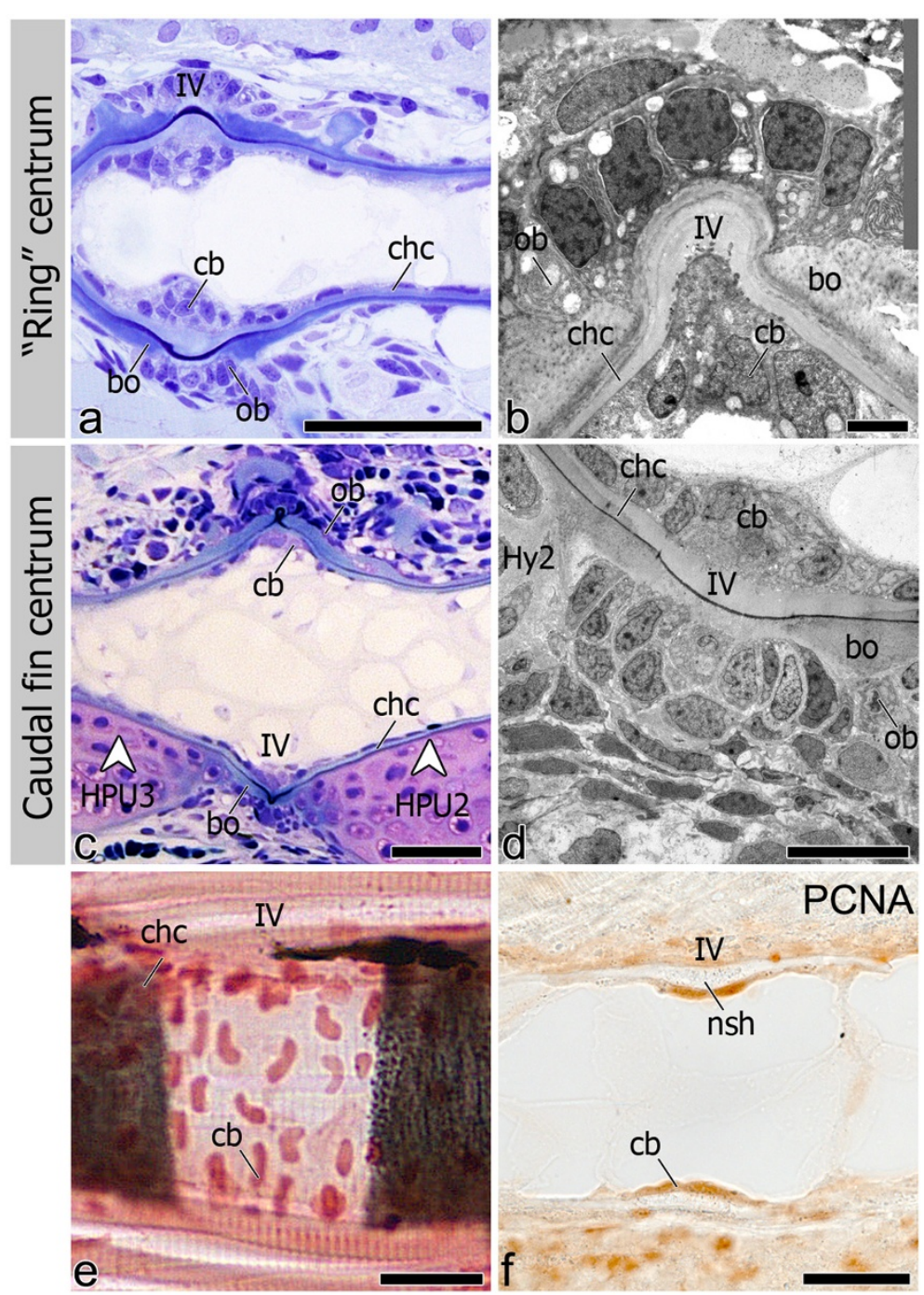

Figure 5 utocentrum development and chordoblast positioning in the intervertebral space. Lateral view of (a) Toluidine blue stained section shows bone (bo) deposition around the chordacentrum (chc), forming the autocentrum in "ring" vertebrae. (b) TEM micrograph showing the intervertebral region (IV). Osteoblasts (ob) are clearly associated with bone deposition. (c) Autocentrum formation also follows chordacentrum development in caudal fin vertebrae although with apparent less amount of bone and osteoblasts due to the presence of the cartilaginous arches (white arrowheads). (d) TEM micrograph of the intervertebral (IV) region between two caudal fin centra showing the bone associated osteoblasts. (e) Sagittal section through the notochord at the level of the IV space. Once chordacentra are fully defined, as shown by von Kossa staining, chordoblasts (cb) tend to accumulate in the intervertebral region, acquiring an oblong shape, larger size, and positioning in a dorsalventral direction. (f) Sagittal section through the notochord at the level of the IV space. At this stage chordoblasts become highly proliferative, as confirmed by PCNA positive staining. Sections from panels a-d are from $11 \mathrm{~mm}$ TL fish, while e-f represent an earlier developmental stage with 6 mm and 6.2 mm TL fish, respectively. Further abbreviations: HPU2-3 - Haemal arch of Preural 2 and 3; Hy2 - Hypural 2; nsh - notochord sheath. Scale bars (a, c): $50 \mu \mathrm{m}$; (b, d): $10 \mu \mathrm{m}$; (e, f): $30 \mu \mathrm{m}$.

and caudal fin), occurs within the notochord sheath, establishing the chordacentrum. These are the first indications of segmented units in the zebrafish notochord. Other authors have already described that early centrum mineralization in teleosts occurs within the notochord sheath $[2,12,13,19,38,39]$. In addition, the notochord may actively contribute to segmentation and centrum formation $[2,12,20]$.
Thus, while the chordacentrum is always established through mineralization of the notochord sheath, the pattern of mineralization differs between caudal fin and remaining vertebral regions: (1) a caudal fin centrum mineralizes after arch formation, while a "ring" centrum is always formed prior to haemal or neural arches, (2) the modified arches from caudal fin vertebrae are composed of cartilage while "ring" centra outside the Weberian 


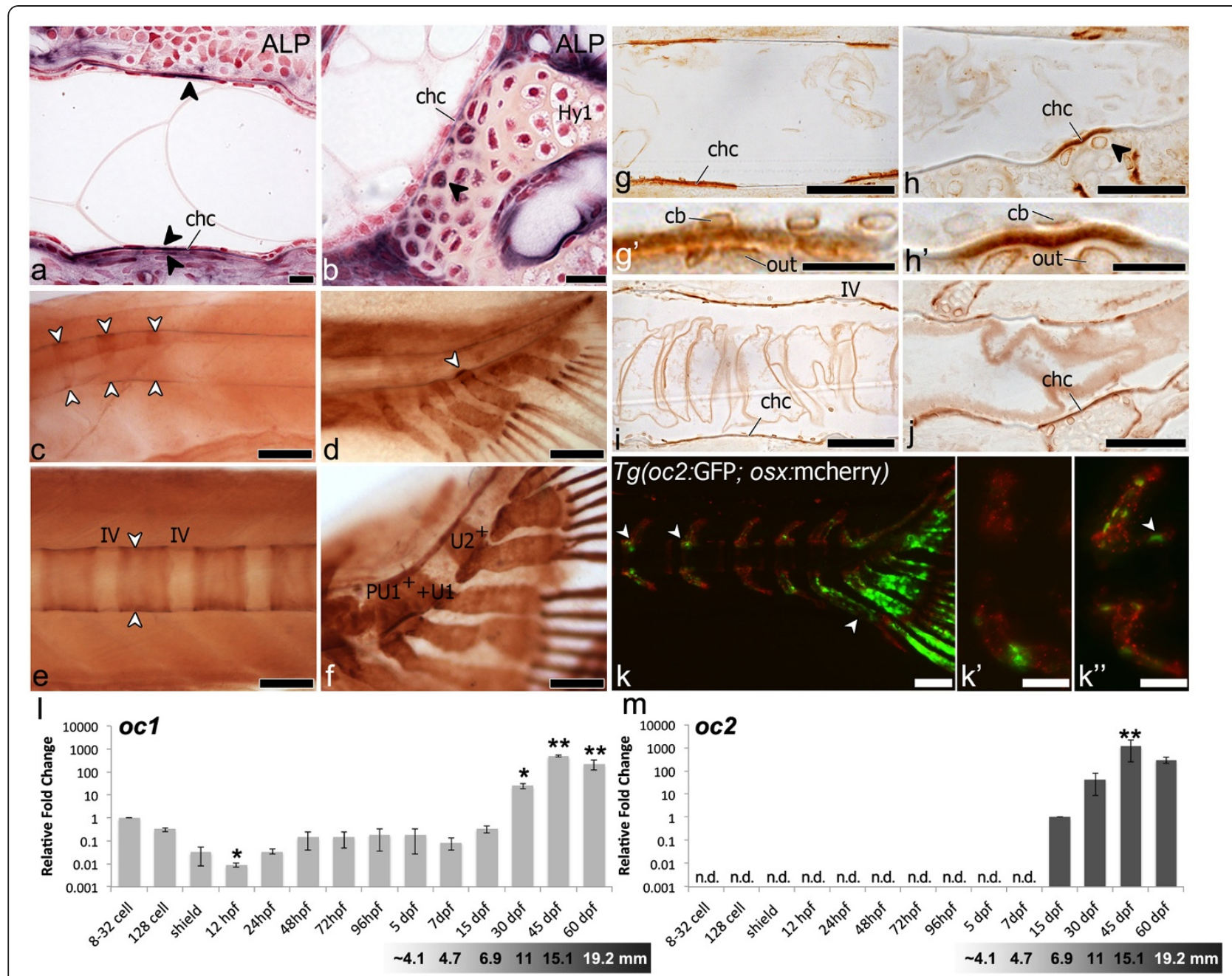

Figure 6 Mineralization and centrum formation, lateral views, anterior left. (a) ALP in a "ring"-centrum (5.0mm TL) adjacent to chordacentrum (chc) mineralization site (arrowheads). (b) In caudal fin centrum (6.2 $\mathrm{mm}$ TL) ALP (arrowhead) in arch-chondrocytes next to chordacentrum. Fast red counterstaining. Osteocalcin (arrowheads) in early mineralized (c) "ring"-centra (4mm TL), and (d) caudal fin centra (5.9mm TL). Osteocalcin in later stages: (e) "Ring"-centra (5.9 mm TL), incremental marks (arrowheads), and (f) caudal fin centra, uniform staining. Sections of wholemount Osteocalcin immunostaining $(\mathbf{g}-\mathbf{j})$. In early chordacentra $(5.9 \mathrm{~mm} \mathrm{TL})$ Osteocalcin accumulates in the notochord sheath in: (g) "ring"-centra and (h) caudal fin centra. Co-localization with arch attachment (arrowhead). (g') Detail of (g). Chordoblasts (cb), outer cells (out). (h') Detail of (h). Osteocalcin-positive chondrocytes (out). In advanced chordacentra (i, j) uniform Osteocalcin accumulation in the matrix, $6.1 \mathrm{~mm}$ and 6.9mm TL. (k) Tg(oc2:gfp; osx:mcherry) transgenic fish, 12mm TL. oc2-positive cells (green), at neural and haemal arches next to "ring"-centra (arrowheads). Osx-positive cells (red) cover vertebral centra. Gradient between ( $\mathbf{k}^{\prime}$ ) less developed (oc2-negative) and ( $\mathbf{k}^{\prime \prime}$ ) more developed (oc2-positive) centra. (k") Oc2 cells (white-arrowhead) next to an autocentrum. (I, m) qPCR, relative gene expression. oc1 and oc2. First detection of transcripts is the reference, represented by a 1-fold change (oc1:8-32 cells, oc2: 15dpf). Oc1, maternally transcribed, decreases at 12hpf ( $p<0.01$ ), increases after $30 \mathrm{dpf}(p<0.01)$. Oc2, detected at $15 \mathrm{dpf}$, increases at $45 \mathrm{dpf}(\mathrm{p}<0.001)$. Age-size conversion under graphs. Hy1 - Hypural 1 ; IV intervertebral space; n.d. - not detected. Scale bars: (a-b, $\left.\left.\mathbf{g}^{\prime}-\mathbf{h}^{\prime}\right) 10 \mu \mathrm{m} ;(\mathbf{c}-\mathbf{f}, \mathbf{k}) 1 \mathrm{~mm} ; \mathbf{( g - j}, \mathbf{k}^{\prime}-\mathbf{k}^{\prime \prime}\right) 0.5 \mathrm{~mm}$.

apparatus are associated to arches formed by intramembranous ossification; and (3) caudal fin centra display a basiventral origin of mineralization, while all other vertebrae start with a "ring"-shaped mineralization.

Arch histogenesis appears to be a clear mark that distinguishes caudal fin vertebrae from the remaining regions. A similar, regional distinct pattern of mineralization has been observed in medaka, with cartilaginous arches in the caudal fin region and intramembranous arches in the anterior part of the vertebral column [19,40]. Although notochord mineralization of anterior centra in medaka starts dorsal, subsequently chordacentrum mineralization will proceed as "ring" centra [19]. Yet, "ring" notochordbased centrum formation, is not an unique feature of zebrafish and medaka, occurring also in other taxa [41]. Considering caudal fin centra of zebrafish and medaka, both display similar patterns of mineralization [40], linked to the presence of modified cartilaginous arches. 
Many basal ray-finned fishes have cartilaginous arches directly attached to an unconstricted notochord [18] suggesting that cartilaginous arches are an ancestral feature. Therefore, the caudal fin endoskeleton of zebrafish, and also medaka, appear to display the evolutionarily conserved condition, with cartilaginous arch formation.

Mineralization in the caudal fin centra shows a clear association with attachment sites of the cartilaginous haemal arches to the notochord (basiventral mineralization pattern). The association between basiventral mineralization and presence of cartilaginous haemal arches has also been described in other teleost species, such as the Goldeye (Hiodon alosoides) [42], Atlantic salmon [2] and White seabream (Diplodus sargus) [43]. In these species too, centrum mineralization originates exactly where the cartilaginous haemal arches are attached to the notochord. Mineralization then progresses from a basiventral origin through bilateral wedge-shaped areas that meet dorsally.

Moreover, we have identified mineralization related proteins in the chondrocytes of the cartilaginous arches, in the immediate vicinity of the area of the incipient mineralization of the notochord. This supports the possible role of the cartilaginous arches in early centrum establishment, a hypothesis that will be discussed in more detail in the next section.

The cartilaginous arches appear to be strictly associated not only with chordacentrum formation but also with the start of autocentrum formation, given that the arches are directly attached to the notochord, affecting bone deposition around the notochord.

The type of arches and associated pattern of centrum mineralization appears to be correlated not only to the formation of the vertebral bodies but also to their ability to fuse or stay as individual units (Figure 7). In the medaka bis (biaxial symmetries) mutant, centra mineralize at sites where ectopic hypurals attach to the notochord, leading to the development of fused centra [40]. Thus, it is tempting to suggest from the zebrafish and medaka data, that the cartilaginous arches have a role in centrum mineralization. Perhaps the predisposition to develop vertebral fusions is related to a specific mineralization pattern with basiventral origin (cartilaginous arch associated).

\section{Distribution of notochord inner and outer cells during centrum formation}

In Atlantic salmon, notochord sheath mineralization is preceded by an apparent segmentation of the chordoblast layer [2]. The same holds for medaka (PEW personal observations). In contrast, differential chordoblast distribution in zebrafish is only clearly observed after chordacentrum mineralization, with few scattered squamous cells in the mineralized area and large, dorso-ventrally oriented, highly proliferative cells in the intervertebral region.

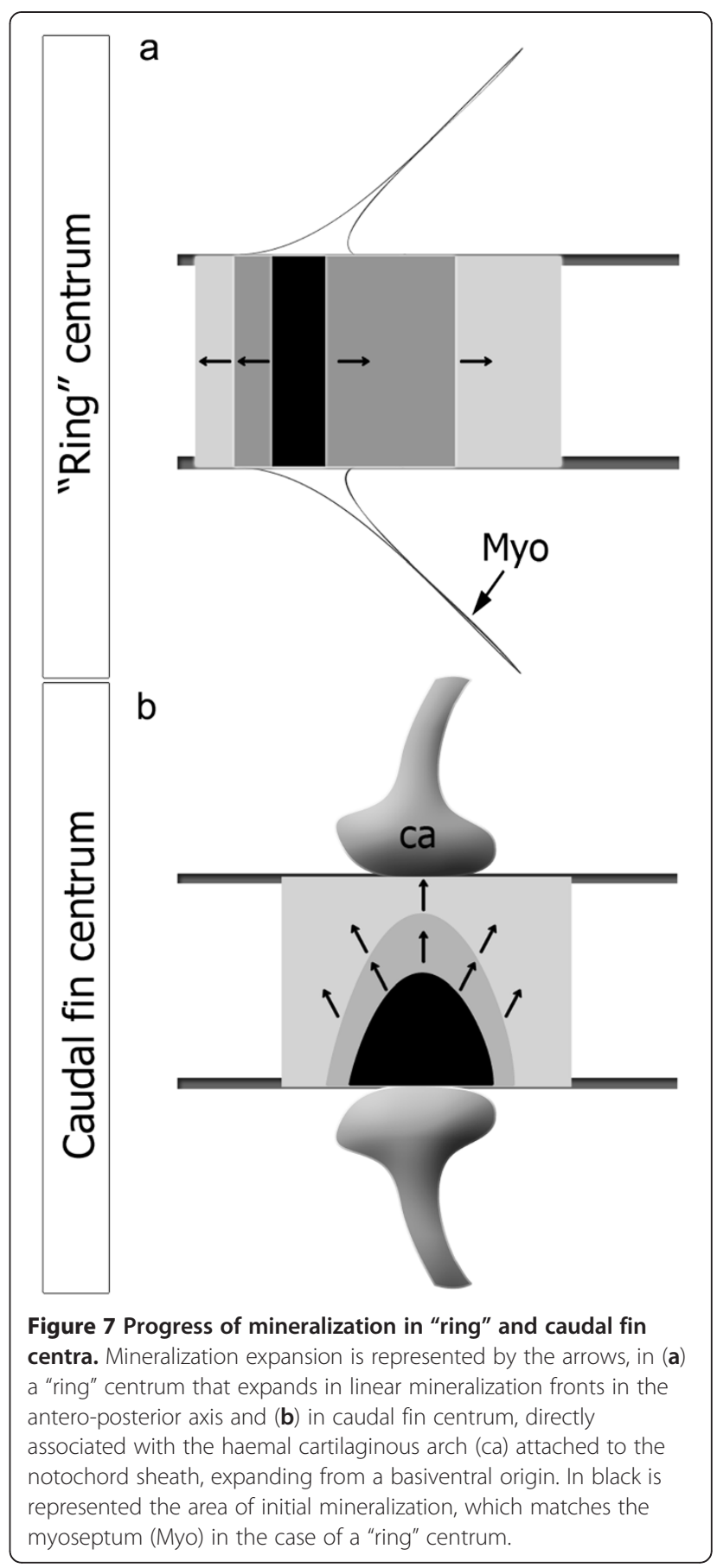

Regarding notochord outer cells, it appears that the segmental pattern of centra in the caudal fin region is associated with the anatomical pattern of arches. In contrast, no association can be found in "ring" centra between outer cell distribution and early chordacentrum formation. The latter is in agreement with the data from zebrafish fused somite mutants ( $f s$ ), where paraxial mesoderm lacks a proper segmentation [44]. This mutant shows fusion of vertebral arches, while vertebral 
centra are individualized, suggesting that centrum segmentation does not rely on sclerotome patterning only. The resegmentation process in zebrafish has been suggested to follow non-lineage restricted compartments, where one somite contributes to more than one vertebral body, independently of the antero-posterior somitic domains (leaky-resegmentation) [1].

Although mineralization is not preceded by a clear pattern of inner or outer cell distribution (exceptions are arch-chondrocytes in the caudal fin), these cells may nevertheless contribute to centrum mineralization. In Atlantic salmon, initial centrum mineralization has been related to chordoblasts, followed by sclerotome-derived bone formation $[2,10]$. Different from Atlantic salmon, in medaka sclerotome-derived osteoblasts, with no input of chordoblasts, have been described to form vertebral centra $[19,35]$. Yet, recent data show that conditional ablation of osteoblasts in medaka maintains notochord mineralization and even leads to vertebral fusion [20]. This suggested that notochord cells have the ability to induce mineralization of the notochord sheath. This is consistent with studies in zebrafish $[12,45]$ that show that notochord cell ablation prevents early centrum mineralization.

\section{Osteocalcin and chordacentrum formation}

Osteocalcin is the most abundant noncollagenous protein in bone of vertebrates, including all teleosts analyzed so far [46]. Although Osteocalcin was already described in the vertebral bodies of teleosts including zebrafish [47-50], no previous reports demonstrated Oc in early notochordal mineralization events. Thus, the presence of Oc in stages of chordacentrum mineralization has to be considered in a perspective different from that of regular bone formation.

Within teleosts, Osteocalcin is represented by two distinct isoforms (Oc1 and Oc2) [25,51], encoded by two different genes, which were proposed to originate from a duplication event [25]. Analysis of relative gene expression levels by qPCR for oc1 and oc 2 showed that $o c 2$ expression is first detected after $7 \mathrm{dpf}$, while $o c 1$ is maternally transcribed, suggesting a different role of the two isoforms. In fact, oc1 is detected prior to any osteoblast differentiation or mineralization event. This leads to the hypothesis that $o c 1$ must be involved in processes prior to bone formation. Detection of Oc1 by immunostaining shows that this protein accumulates exactly where mineralization of the chordacentrum occurs. In the "ring" centra, the origin of the secreted protein is difficult to assess, due to the squamous morphology of the cells of the notochord epithelium and the inconspicuous presence of cells outside the notochord. In the caudal fin region, ALP positive chondrocytes, directly adjoining the mineralizing notochord sheath, are positive for Oc immunostaining, as well as notochord inner cells. In the $\mathrm{Tg}$ (oc2:gfp; osx:mcherry) fish, oc2 expression was located at the bone of arches of the "ring" centra, that form via intramembranous bone formation. This time point corresponds to the phase of autocentrum mineralization, as previously described in medaka [52]. Therefore, our results suggest that Oc1, but not Oc2, is connected to chordacentrum mineralization. Likewise, in larval and juvenile Atlantic cod [53], oc1 and oc2 are expressed in different cells associated with mineralizing structures. In Atlantic salmon, some mineralized areas with reduced expression of osteocalcin (oc1) were considered to be associated with expression of a second isoform that the authors did not identify [49]. Laizé and co-workers [25] described Oc2 propeptide as serine-rich, potentially phosphorylated and containing acid residues. These characteristics allow this protein to bind numerous calcium ions. If Osteocalcin has an active role in the process of mineralization or if it is a bone-related hormone that passively binds to calcium $[54,55]$, is a current debate and must be further explored.

\section{Conclusions}

In conclusion, we have analyzed distinct mineralization patterns in different regions of the zebrafish vertebral column and related them to the timing and nature of vertebral arch formation. We have examined the distribution of cells within and outside the notochord, and critically assessed their potential contribution to chordacentrum and autocentrum formation. If notochord mineralization occurs prior to arch formation, the mineralization of the notochord sheath is ring-shaped. If notochord mineralization occurs after cartilaginous arch formation, mineralization of the notochord sheath starts at the insertion point of the arches, with a basiventral origin. Finally, we have detected Oc1 in the notochord sheath during chordacentrum formation, whereas oc2 was only expressed later in association with bone formation. These results emphasize the need to better characterize the function of both osteocalcin genes in zebrafish and throughout the vertebrate clade.

\section{Methods}

\section{Ethics statement on animal experiments}

Animal handling and experiments were legally accredited by the Portuguese Direcção Geral de Veterinária (DGV) and all the experimental procedures involving animals followed the EU (Directive 86/609/CEE) and National (Directives 1005/92 from October 23, 466/95 from May 17 and 1 1131/97 from November 7) legislation for animal experimentation and welfare.

\section{Sampling and wholemount skeletal analysis}

To establish a timeline of events for early vertebrae development, an ontogenic series of Danio rerio was studied. Zebrafish eggs were obtained from natural spawning 
of wild-type fish and larvae were maintained and reared at standard conditions [56]. Fish were collected at size intervals of $0.1 \mathrm{~mm}$, between 4.0 and $8.0 \mathrm{~mm}$ of total length (TL). Similar-sized specimens were always selected among age-matched fish in order to avoid additional interspecific variation.

Larvae were euthanized with a lethal dose of MS222 (Sigma-Aldrich, St. Louis, MO) and fixed for $24 \mathrm{~h}$ in $4 \%$ buffered paraformaldehyde at $4^{\circ} \mathrm{C}$.

Early mineralization stages of the vertebral bodies were observed following 10 minutes staining with $0.01 \%$ alizarin red $\mathrm{S}$ in $70 \%$ ethanol solution. Specimens were observed under a Zeiss Axio Imager microscope, through fluorescence detection [57].

\section{Light and transmission electron microscopy (TEM)}

Zebrafish specimens of 5.0 and $11.0 \mathrm{~mm}$ TL with no pre-staining were fixed in a mixture of $1.5 \%$ glutaraldehyde and $1.5 \%$ paraformaldehyde in $0.1 \mathrm{M}$ cacodylate buffer and processed for embedding in Epon, according to procedures previously described [58]. Parasagittal 1 $\mu \mathrm{m}$ semi-thin sections of the sites of interest were stained with toluidine blue for $1-2$ min $(0.2 \%$ toluidine blue, $\left.2 \% \quad \mathrm{Na}_{2} \mathrm{CO}_{3}\right)$, rinsed with water, air-dried and mounted with DPX (Fluka, Buchs, Switzerland). Ultrathin sections were contrasted with uranyl acetate and lead citrate and observed with a Jeol JEM 1010 (Jeol, Tokyo, Japan), operating at $60 \mathrm{kV}$. Images were digitized using a DITABIS system (Pforzheim, Germany).

\section{Identification of sites of mineral deposition and Alkaline phosphatase activity (ALP)}

To determine sites of mineral deposition and of Alkaline phosphatase (ALP) activity during centrum formation, specimens ranging from 5.0 to $6.5 \mathrm{~mm}$ TL were dehydrated and embedded in glycol methacrylate, as previously described [59], and sectioned at $5 \mu \mathrm{m}$.

For detection of minerals, a silver nitrate coupling method, according to von Kossa [60], was used. Sections were counterstained with neutral red. Slides were examined for the appearance of optimal signal, rinsed in distilled water and mounted with DPX (Sigma-Aldrich, St. Louis, MO).

Alkaline phosphatase activity was detected using a previously described method [61] with some modification. Briefly, slides were incubated in staining buffer $(100 \mathrm{mM}$ Tris/HCl, pH 9.5; $50 \mathrm{mM} \mathrm{MgCl}_{2} ; 100 \mathrm{mM} \mathrm{NaCl}$ ) for 10 min. ALP was demonstrated by adding 4-nitro blue tetrazolium chloride (NBT; $0.38 \mathrm{mg} \mathrm{ml}^{-1}$; Roche) and 5bromo-4-chloro-3-indolyl phosphate (BCIP; $0.175 \mathrm{mg}$ $\mathrm{ml}^{-1}$; Roche) to the buffer solution, for a maximum of 30 min at $37^{\circ} \mathrm{C}$, in the dark. Negative control slides were incubated for $10 \mathrm{~min}$ at $85^{\circ} \mathrm{C}$ in staining buffer prior to addition of NBT and BCIP. Slides were examined for the appearance of optimal signal-noise ratio, counterstained with Nuclear Fast Red Solution (Sigma-Aldrich, St. Louis, MO) and mounted in DPX (Sigma-Aldrich, St. Louis, MO).

\section{Immunolocalization of PCNA, Osteocalcin and Collagen type II}

For detection of cell proliferation through Proliferating cell nuclear antigen (PCNA) immunolocalization, $6.2 \mathrm{~mm}$ TL fish were paraffin-embedded according to routine procedures and serially sectioned at $7 \mu \mathrm{m}$. A mouse monoclonal primary antibody produced against human antigen (Sigma-Aldrich, St. Louis, MO, dilution 1:1000) was used [62] together with a goat polyclonal antimouse immunoglobulin biotin-coupled secondary antibody (Dako, dilution 1:500).

Immunohistochemical detection of Osteocalcin and Collagen type II was performed on fish of 4 to $6.5 \mathrm{~mm}$ $\mathrm{TL}$ as wholemount staining, according to a procedure previously described [63], using an anti-meagre (Argyrosomus regius) Osteocalcin rabbit polyclonal primary antibody, previously validated for zebrafish [36]. For Collagen type II an anti-chicken mouse antibody (II-II6B3, Hybridoma Bank) previously validated for zebrafish [64], was used. Control fish were treated with secondary antibody alone.

Osteocalcin stained specimens were subsequently dehydrated, embedded in epon, serially sectioned at 4 $\mu \mathrm{m}$ and mounted with DPX (Sigma-Aldrich, St. Louis, MO), to achieve a more detailed analysis. Wholemount fish stained for Collagen type II were observed using a Leica MZ Apo stereomicroscope. Sections were observed using a Zeiss Axio Imager Microscope and photographed using an Axiocam MRC videocamera.

\section{oc2 transgenic line}

The transgenic zebrafish line $\operatorname{Tg}$ (oc2:gfp; osx:mcherry), previously described by [65], was provided by Stefan Schulte-Merker from Hubrecht Institute-KNAW and University Medical Centre (Uppsalalaan 8, 3584 CT Utrecht, The Netherlands).

\section{RNA extraction and oc1/oc2 quantitative expression analysis}

Total RNA was extracted from a pool of up to twenty specimens following the Chomczynski and Sacchi method [66]. Samples were collected at stages 8-32 or 128 cells, at shield stage, at 12, 24, 48, 72 and 96 hours postfertilization (hpf) and at 5, 7, 15, 30, 45 and 60 days post-fertilization (dpf). To prevent genomic DNA contamination, following RNA extraction, samples were DNase treated with RQ1 DNase (Promega, Madison, WI) according to the manufacturer's protocol, followed by a phenol-chlorophorm purification step. RNA 
quantity and quality was determined by spectrophotometry (NanoDrop ND-1000, Thermo Scientific) and electrophoresis.

cDNA was prepared from $1 \mu \mathrm{g}$ of total RNA from each sample using Moloney-murine leukemia virus (M-MLV) reverse transcriptase (Invitrogen), RNase Out (Invitrogen), and an oligo(dT) adapter (5'-ACGCGTCGACCTCGA GATCGATG(T)13-3') in a total volume of $20 \mu \mathrm{l}$ for $1 \mathrm{~h}$ at $37^{\circ} \mathrm{C}$. For quantitative real-time PCR a StepOnePlus 96 (Applied Biosystems) was used together with $1 \times$ SsoFastTM EvaGreen Supermix (BioRad, Richmond, USA), $0.2 \mu \mathrm{M}$ of forward (Oc1: 5'-GAAGCGAACATGAAGA GTCTGACAGTCC-3'; Oc2: 5'-CCAACTCCGCATCAG ACTCCGCATCA-3') and reverse (Oc1- $5^{\prime}$-TTTATAGGC GGCGATGATTCC-3'; Oc2: 5'-AGCAACACTCCGCTT CAGCAGCACAT-3') primers and $200 \mathrm{ng}$ of reversetranscribed RNA. PCR conditions were $15 \mathrm{~min}$ at $95^{\circ} \mathrm{C}$ followed by $40-50$ amplification cycles (each cycle is 30 $\mathrm{s}$ at $95^{\circ} \mathrm{C}, 15 \mathrm{~s}$ at $68^{\circ} \mathrm{C}$ ). Expression values were normalized using the Elongation factor $1 \alpha$ (Ef1 $\alpha$ ) housekeeping gene [67]. Gel electrophoresis and melt curve analysis were used to confirm specific product formation.

All data were statistically analyzed using a non-parametric Kruskal-Wallis test, followed by Wilcoxon multiple comparison with the GraphPad Prism software.

\section{Terminology}

The subdivision of the vertebral column in different regions is based on the nomenclatures of Arratia et al. [16], Bird and Mabee [31] and Nybelin [68] (Figure 1). From anterior to posterior, vertebrae were identified as (1) Weberian vertebrae, (2) abdominal vertebrae (ribbearing with open haemal arches and without haemal spines), (3) caudal vertebrae (with haemal arches closed), and (4) caudal fin vertebrae (with modified haemal and neural arches and respective spines). The nomenclature of the Weberian apparatus follows [31]. The caudal fin vertebrae nomenclature follows Patterson [69], adapted by Arratia and Schultze [70] and Bensimon-Brito et al. [32]. The caudal fin vertebral region contains preural and ural vertebral bodies. Preural vertebral bodies (abbreviated as PU) have haemal and neural arches that support the caudal fin. Ural vertebral bodies (briefly urals, abbreviated as U) support the caudal fin with modified haemal arches that do not enclose the caudal artery. A plus sign is added in superscript when a vertebral centrum is derived from a fusion event (compound centrum), as described previously [32].

\section{Competing interests}

The funding agencies had no role in study design, data collection and analysis, decision to publish, or preparation of the manuscript. The authors have declared no competing interests.

\section{Authors' contributions}

Conceived and designed the experiments: ABB, MLC, AH, PEW. Performed the experiments: ABB and JC. Analyzed the data: ABB, JC, MLC, AH, PEW. Contributed reagents/materials/analysis tools: MLC, AH. PEW. Contributed to the writing of the paper: ABB, MLC, AH, PEW. All authors read and approved the final manuscript.

\section{Acknowledgements}

A. Bensimon-Brito acknowledges a FCT PhD fellowship SFRH/BD/40573/2007 and is presently the recipient of an ERC Reseal (2007-StG-208631) fellowship, J. Cardeira is the recipient of a CCMAR fellowship CCMAR/BI/0029/2009 and A. Huysseune and P.E. Witten acknowledge a grant from FWO 3G.0040.08. LC acknowledges CCMAR funding. The authors thank Stefan Schulte-Merker for providing the transgenic zebrafish line $\operatorname{Tg}(o c 2$ :gfp; osx:mcherry). For assistance in sample collection we thank G. Dionísio and R. Peres dos Santos. For technical assistance we thank Barbara Verstraeten, Myriam Claeys, Tommy D'heuvaert and Jasper Dewit.

\section{Author details}

${ }^{1} \mathrm{PhD}$ Program in Biomedical Sciences, University of Algarve, Faro, Portugal. ${ }^{2}$ Center of Marine Sciences - CCMar, University of Algarve, Faro, Portugal. ${ }^{3}$ Evolutionary Developmental Biology, Biology Department, Ghent University, Ghent, Belgium. ${ }^{4}$ Dept. of Biomedical Sciences and Medicine, University of Algarve, Faro, Portugal. ${ }^{5}$ Present address: CEDOC - Faculdade de Ciências Médicas, FCM Universidade Nova de Lisboa, Lisbon, Portugal.

Received: 12 July 2012 Accepted: 3 October 2012 Published: 9 October 2012

\section{References}

1. Morin-Kensicki EM, Melancon E, Eisen JS: Segmental relationship between somites and vertebral column in zebrafish. Development 2002, 129:3851-3386

2. Grotmol S, Kryvi H, Nordvik K, Totland GK: Notochord segmentation may lay down the pathway for the development of the vertebral bodies in the Atlantic salmon. Anat Embryol 2003, 207:263-272.

3. Turnpenny PD, Alman B, Cornier AS, Giampietro PF, Offiah A, Tassy O, Pourquié $\mathrm{O}$, Kusumi $\mathrm{K}$, Dunwoodie S: Abnormal vertebral segmentation and the notch signaling pathway in man. Dev Dyn 2007, 236(6):1456-1474.

4. Hall BK: Evolutionary consequences of skeletal differentiation. Am Zool 1975, 15:329-350.

5. Kaplan KM, Spivak JM, Bendo JA: Embryology of the spine and associated congenital abnormalities. Spine J 2005, 5(5):564-576.

6. Christ B, Huang R, Wilting J: The development of the avian vertebral column. Anat Embryol 2000, 202:179-194.

7. Kahane N, Cinnamon Y, Kalcheim C: The origin and fate of pioneer myotomal cells in the avian embryo. Mech Dev 1998, 74:59-73.

8. Christ B, Huang R, Scaal M: Formation and differentiation of the avian sclerotome. Anat Embryol 2004, 208:333-350.

9. Stemple DL: Structure and function of the notochord: an essential organ for chordate development. Development 2005, 132:2503-2512.

10. Grotmol S, Nordvik K, Kryvi H, Totland GK: A segmental pattern of alkaline phosphatase activity within the notochord coincides with the initial formation of the vertebral bodies. J Anat 2005, 206:427-436.

11. Schmitz RJ: Comparative ultrastructure of the cellular components of the unconstricted notochord in the sturgeon and the lungfish. J Morphol 1998, 236:75-104.

12. Fleming A, Keynes $R$, Tannahill D: A central role for the notochord in vertebral patterning. Development 2004, 131:873-880.

13. Huxley TH: Observations on the development of some parts of the skeleton of fishes. Q J Microsc Sci 1859, 7:33-46.

14. François $Y$ : Structure et développement de la vertèbre de Salmo et des téléostéens. Archives de Zoologie Experimentale et Generale 1966, 107:287-328.

15. Bensimon-Brito A, Cancela ML, Huysseune A, Witten PE: Vestiges, rudiments and fusion events: the zebrafish caudal fin endoskeleton in an evo-devo perspective. Evol Dev 2012, 14(1):116-127.

16. Arratia G, Schultze H-P, Casciotta J: Vertebral column and associated elements in Dipnoans and comparison with other fishes: Development and homology. J Morphol 2001, 250:101-172. 
17. Gavaia PJ, Simes DC, Ortiz-Delgado JB, Viegas CSB, Pinto JP, Kelsh RN, Sarasquete MC, Cancela ML: Osteocalcin and matrix Gla protein in zebrafish (Danio rerio) and Senegal sole (Solea senegalensis): Comparative gene and protein expression during larval development through adulthood. Gene Expr Patterns 2006, 6(6):637-652.

18. Lauder GV: On the relationship of the myotome to the axial skeleton in vertebrate evolution. Paleobiology 1980, 6(1):51-56.

19. Inohaya $K$, Takano $Y$, Kudo A: The Teleost intervertebral region acts as a growth center of the centrum: In vivo visualization of osteoblasts and their progenitors in transgenic fish. Dev Dyn 2007, 236:3031-3046

20. Willems B, Büttner A, Huysseune A, Renn J, Witten PE, Winkler C: Conditional ablation of osteoblasts in medaka. Dev Biol 2012, 364:128-137.

21. Huysseune A, Takle H, Soenens M, Taerwe K, Witten PE: Unique and shared gene expression patterns in Atlantic salmon (Salmo salar) tooth development. Developmental Genes and Evolution 2008, 218:427-437.

22. Pullig O, Weseloh G, Ronneberger D-L, Käkönen S-M, Swoboda B: Chondrocyte differentiation in Human osteoarthritis: Expression of osteocalcin in normal and osteoarthritic cartilage and bone. Calcif Tissue Int 2000, 67:230-240

23. Aizawa T, Roach HI, Kokubun S, Tanaka Y: Changes in the expression of Fas, osteonectin and osteocalcin with age in the rabbit growth plate. The Journal of Bone and Joint Surgery (Br) 1998, 80-B(5):880-887.

24. Neugebauer BM, Monroe MA, Broess M, Gerstenfeld LC, Hauschka PV: Characterization of structural sequences in the chicken osteocalcin gene: Expression of osteocalcin by maturing osteoblasts and by hypertrophic chondrocytes in vitro. J Bone Miner Res 1995, 10(1):157-163.

25. Laizé V, Viegas CSB, Price PA, Cancela ML: Identification of an osteocalcin isoform in fish with a large acidic prodomain. J Biol Chem 2006, 281(22):15037-15043

26. Fjelldal $P G$, Hansen $T$, Breck $O$, Ornsrud $R$, Lock EJ, Waagbø $R$, Wargelius A, Witten PE: Vertebral deformities in farmed Atlantic salmon (Salmo salar L.) - etiology and pathology. J Appl Ichthyol 2012, 28(3):433-440

27. Ward $A B$, Brainerd EL: Evolution of axial patterning in elongate fishes. Biol J Linn Soc 2007, 90:97-116.

28. Wargelius A, Fjelldal PG, Hansen T: Heat shock during early somitogenesis induces caudal vertebral column defects in Atlantic salmon (Salmo salar). Dev Genes Evol 2005, 215(7):350-357.

29. Bird NC, Hernandez LP: Building an evolutionary innovation: differential growth in the modified vertebral elements of the zebrafish Weberian apparatus. Zoology 2009, 112(2):97-112.

30. Ferreri F, Nicolais C, Boglione C, Bertolini B: Skeletal characterization of wild and reared zebrafish: anomalies and meristic characters. J Fish Biol 2000, 56(5):1115-1128.

31. Bird NC, Mabee PM: Developmental morphology of the axial skeleton of the zebrafish, Danio rerio (Ostariophysi: Cyprinidae). Dev Dyn 2003, 228(3):337-357.

32. Bensimon-Brito A, Cancela ML, Huysseune A, Witten PE: The zebrafish (Danio rerio) caudal complex: a model to study vertebral body fusion. J Appl Ichthyol 2010, 26(2):235-238.

33. Witten PE, Obach A, Huysseune A, Baeverfjord G: Vertebrae fusion in Atlantic salmon (Salmo salar): development, aggravation and pathways of containment. Aquaculture 2006, 258(1-4):164-172.

34. Fjelldal PG, Nordgarden U, Wargelius A, Taranger GL, Waagbø R, Olsen RE: Effects of vegetable feed ingredients on bone health in Atlantic salmon. J Appl Ichthyol 2010, 26(2):327-333.

35. Ekanayake $S$, Hall BK: The development of acellularity of the vertebral bone of the Japanese Medaka, Oryzias latipes (Teleostei; Cyprinidontidae). J Morphol 1987, 193:253-261.

36. Simes DC, Williamson MK, Schaff BJ, Gavaia PJ, Ingleton PM, Price PA, Cancela ML: Characterization of osteocalcin (BGP) and matrix gla protein (MGP) fish specific antibodies: validation for immunodetection studies in lower vertebrates. Calcif Tissue Int 2004, 74:170-180.

37. Du SJ, Frenkel V, Kindschi G, Zohar Y: Visualizing normal and defective bone development in Zebrafish embryos using the fluorescent chromophore calcein. Dev Biol 2001, 238:239-246.

38. Nordvik K, Kryvi H, Totland GK, Grotmol S: The salmon vertebral body develops through mineralization of two preformed tissues that are encompassed by two layers of bone. J Anat 2005, 206:103-114.
39. Kölliker A: Weitere Beobachtungen über die Wirbel der Selachier, insbesondere über die Wirbel der Lamnoidei, nebst allgemeinen Bemerkungen über die Bildung der Wirbel der Plagiostomen. Frankfurt: Verlag HL. Bröuner; 1863

40. Hibiya K, Katsumoto T, Kondo T, Kitabayashi I, Kudo A: Brpf1, a subunit of the MOZ histone acetyl transferase complex, maintains expression of anterior and posterior Hox genes for proper patterning of craniofacial and caudal skeletons. Dev Biol 2009, 329:176-190.

41. Laerm J: The origin and homology of the chondrostean vertebral centrum. Can J Zool 1979, 57(3):475-485.

42. Schultze H-P, Arratia G: Reevaluation of the caudal skeleton of some actinopterygian fishes: Il. Hiodon, Elops, and Albula. J Morphol 1988, 195(3):257-303.

43. Koumoundouros G, Sfakianakis DG, Maingot E, Divanach P, Kentouri M: Osteological development of the vertebral column and of the fins in Diplodus sargus (Teleostei: Perciformes: Sparidae). Mar Biol 2001, 139:853-862.

44. van Eeden FJM, Granato M, Schach U, Brand M, Furutani-Seiki M, Haffter P Hammerschmidt M, Heisenberg C-P, Jiang Y-J, Kane DA, et al: Mutations affecting somite formation and patterning in the zebrafish, Danio rerio. Development 1996, 123:153-164.

45. Fleming A, Keynes RJ, Tannahill D: The role of the notochord in vertebral column formation. J Anat 2001, 199(1-2):177-180.

46. Nishimoto SK, Waite JH, Nishimoto M, Kriwacki RW: Structure, activity, and distribution of fish osteocalcin. J Biol Chem 2003, 278(14):11843-11848.

47. Simes DC, Williamson MK, Ortiz-Delgado JB, Viegas CSB, Price PA, Cancela ML: Purification of Matrix Gla Protein from a marine teleost fish, Argyrosomus regius: Calcified cartilage and not bone as the primary site of MGP accumulation in fish. J Bone Miner Res 2003, 18(2):244-259.

48. Ytteborg E, Togersen J, Baeverfjord G, Takle H: Morphological and molecular characterization of developing vertebral fusions using a teleost model. BMC Physiol 2010, 10(13):1-15.

49. Krossøy C, Ornsrud R, Wargelius A: Differential gene expression of bgp and mgp in trabecular and compact bone of Atlantic salmon (Salmo salar L.) verebrae. J Anat 2009, 215:663-672.

50. Pinto JP, Ohresser MCP, Cancela ML: Cloning of the bone Gla protein gene from the teleost fish Sparus aurata. Evidence for overall conservation in gene organization and bone-specific expression from fish to man. Gene Expr Patterns 2001, 270:77-91.

51. Desbois C, Hogue DA, Karsenty G: The mouse osteocalcin gene cluster contains three genes with two separate spatial and temporal patterns of expression. J Biol Chem 1994, 269:1183-1190.

52. Renn J, Winkler C: Characterization of collagen type 10a1 and osteocalcin in early and mature osteoblasts during skeleton formation in medaka. J Appl Ichthyol 2010, 26:196-201.

53. Lie KK, Moren M: Retinoic acid induces two osteocalcin isoforms and inhibits markers of osteoclast activity in Atlantic cod (Gadus morhua) ex vivo cultured craniofacial tissues. Comparative Biochemistry and Physiology, Part A 2012, 161:174-184.

54. Confavreux CB, Levine RL, Karsenty G: A paradigm of integrative physiology, the crosstalk between bone and energy metabolisms. Mol Cell Endocrinol 2009, 310:21-29.

55. Ferron M, Hinoi E, Karsenty G, Ducy P: Osteocalcin differentially regulates cell and adipocyte gene expression and affects the development of metabolic diseases in wild-type mice. Proceedings of the National Academy of Sciences USA 2009, 105(13):5266-5270.

56. Westerfield M: The zebrafish book. A guide for the laboratory use of zebrafish Danio rerio. 4th edition. Eugene: University of Oregon Press; 2000.

57. Connolly MH, Yelick PC: High-throughput methods for visualizing the teleost skeleton: capturing autofluorescence of alizarin red. J Appl Ichthyol 2010, 26:274-277.

58. Huysseune A, Sire JY: Development of cartilage and bone tissues of the anterior part of the mandible in cichlid fish: a light and TEM study. Anat $\operatorname{Rec} 1992,233: 357-375$.

59. Witten PE, Hansen A, Hall BK: Features of mono and multinucleated bone resorbing cells of the zebrafish Danio rerio and their contribution to skeletal development, remodeling and growth. J Morphol 2001, 250:197-207.

60. Schenk RK, Olah AJ, Herrmann W: Preparation of calcified tissues for light microscopy. In Methods of Calcified Tissue Preparation. Edited by Dickson GR. Amsterdam: Elsevier; 1984:1-56 
61. Miyake T, Cameron AM, Hall BK: Stagespecific expression patterns of alkaline phosphatase during development of the first arch skeleton in inbred C57BL/6 mouse embryos. J Anat 1997, 190:239-260.

62. Ortego LS, Hawkins WE, Walker WW, Krol RM, Benson WH: Detection of Proliferating Cell Nuclear antigen in tissues of three small fish species. Biotech Histochem 1994, 69(6):317-323.

63. Verstraeten B, Sanders E, Huysseune A: Whole Mount Immunohistochemistry and In Situ Hybridization of Larval and Adult Zebrafish Dental Tissues. In: Methods Mol Biol. vol. 2012, 887:179-191.

64. Clément A, Wiweger M, Hardt S, Rusch MA, Selleck SB, Chien C-B, Roehl HH, et al: Regulation of Zebrafish Skeletogenesis by ext2/dackel and papst1/ pinscher. PLoS Genet 2008, 4:e1000136.

65. Knopf F, Hammond C, Chekuru A, Kurth T, Hans S, Weber CW, Mahatma G, Fisher S, Brand M, Schulte-Merker S, et al: Bone regenerates via dedifferentiation of osteoblasts in the zebrafish fin. Dev Cell 2011, 20:713-724

66. Chomczynski P, Sacchi N: Single-step method of RNA isolation by acid guanidinium thiocyanate-phenol-chloroform extraction. Anal Biochem 1987, 162:156-159.

67. Tang R, Dodd A, Lai D, Mcnabb WC, Love DR: Validation of Zebrafish (Danio rerio) reference genes for quantitative real-time RT-PCR normalization. Acta Biochim Biophys Sin 2007, 39(5):384-390.

68. Nybelin O: Zur morphologie und terminologie des schwanzskelettes der Actinopterygier. Arkiv fur Zoologi 1963, 15:485-516.

69. Patterson C: The caudal skeleton in Lower Liassic pholidophorid fishes. Bulletin of the British Museum (Natural History) Geology 1968, 16(5):201-239.

70. Arratia G, Schultze H-P: Reevaluation of the caudal skeleton of certain actinopterygian fishes. III. Salmonidae. Homologization of caudal skeletal structures. J Morphol 1992, 214:187-249.

doi:10.1186/1471-213X-12-28

Cite this article as: Bensimon-Brito et al:: Distinct patterns of notochord mineralization in zebrafish coincide with the localization of Osteocalcin isoform 1 during early vertebral centra formation. BMC Developmental Biology 2012 12:28.

\section{Submit your next manuscript to BioMed Central and take full advantage of:}

- Convenient online submission

- Thorough peer review

- No space constraints or color figure charges

- Immediate publication on acceptance

- Inclusion in PubMed, CAS, Scopus and Google Scholar

- Research which is freely available for redistribution 